\title{
Platelet indices and platelet-to-lymphocyte ratio predict coronary chronic total occlusion in patients with acute ST- elevation myocardial infarction
}

\author{
Indicii trombocitari şi raportul trombocite/limfocite prezic ocluzia \\ totală cronică coronariană la pacienţii cu infarct miocardic acut cu \\ supradenivelare de segment $\mathrm{ST}$
}

\author{
Laszlo Hadadi ${ }^{1}$, Ioana Sus ${ }^{2 *}$, Eva Katalin Lakatos ${ }^{1}$, Razvan Constantin Serban ${ }^{2}$, \\ Alina Scridon², Zoltan Demjen ${ }^{3}$, Dan Dobreanu ${ }^{2}$ \\ 1. Department of Internal Medicine, University of Medicine and Pharmacy of Tirgu Mures \\ 2. Department of Physiology, University of Medicine and Pharmacy of Tirgu Mures \\ 3. Department of Cardiology, Emergency Institute for Cardiovascular Diseases and Transplantation, \\ Tirgu Mures
}

\begin{abstract}
Coronary chronic total occlusion (CTO) is caused by organized thrombi or atherosclerotic plaque progression. The presence of a CTO is an independent predictor of mortality in patients presenting with ST-segment elevation myocardial infarction (STEMI). Platelets have a crucial role in the pathophysiology of atherosclerosis. The aim of this retrospective study was to investigate platelet indices as predictors of CTO in patients with STEMI treated with

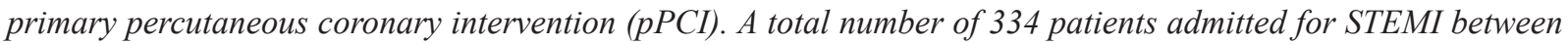
January 2011 and December 2013 were included and divided in two groups based on the presence of CTO (48 patients in CTO+ group, 286 patients in CTO- group). Platelet count, mean platelet volume (MPV), platelet distribution width $(P D W)$, platelet-large cell ratio $(P-L C R)$, lymphocyte and neutrophil count determined on admission were analyzed. MPV was larger in patients with CTO compared with patients without CTO $(p=0.02)$, as were PDW $(p=0.03)$ and P-LCR $(p=0.01)$. Platelet-to-lymphocyte ratio (PLT/LYM) was lower in patients with CTO: 105.2 (75.86-159.1) compared to 137 (97-188.1), $p<0.01$. Receiver-operator characteristic curve analysis identified an area under the curve of 0.61 (95\%CI=0.57-0.67, $p<0.01)$ for PLT/LYM in predicting the presence of a CTO, with a cut-off value at 97.73. Lower values than this were independent predictors of a CTO in multivariate logistic regression analysis, with an Odds Ratio of $2.2(95 \% C I=1.15-4.20, p=0.02)$. Our results support the use of platelet indices and PLT/LYM as predictors of CTO in patients presenting with STEMI.
\end{abstract}

Keywords: acute myocardial infarction, chronic total occlusion, platelets, lymphocytes

*Corresponding author: Ioana Sus, University of Medicine and Pharmacy of Tirgu Mures, Tirgu Mures, Romania, e-mail: susioana@yahoo.com 


\section{Rezumat}

Ocluzia totală cronică coronariană (CTO) este cauzată de trombi organizaţi sau de progresia plăcilor aterosclerotice. Prezenţa unei CTO este un predictor independent pentru mortalitate la pacienţii cu infarct miocardic acut cu supradenivelare de segment ST (STEMI). Trombocitele au un rol central in patofiziologia aterosclerozei. Scopul acestui studiu retrospectiv a fost investigarea indicilor trombocitari ca predictori ai CTO la pacienţii cu STEMI trataţi prin intervenţie coronariană percutană primară (pPCI). Au fost incluşi 334 pacienţi internaţi pentru STEMI în perioada ianuarie 2011 - decembrie 2013, şi împărţiţi în două grupuri în funcţie de prezenţa CTO (48 de pacienţi în grupul CTO+, 286 în grupul CTO-). Au fost analizate numărul de trombocite, volumul trombocitar mediu $(M P V)$, distribuţia plachetelor după volum $(P D W)$, procentul de trombocite mari (P-LCR), numărul de limfocite şi neutrofile, toate determinate la internare. MPV a fost semnificativ mai mare la pacienţii cu CTO faţă de cei fără CTO ( $p=0.02)$, precum şi $P D W(p=0.03)$ şi P-LCR $(p=0.01)$. Raportul trombocite-limfocite (PLT/LYM) a fost mai mic la pacienţii cu CTO: 105.2 (75.86-159.1) comparat cu 137 (97-188.1), p<0.01. Analiza curbei receiver-operator characteristic a identificat o arie sub curbă de $0.61(95 \% C I=0.57-0.67, p<0.01)$ pentru PLT/ LYM ca predictor al prezenţei CTO, cu o valoare cut-off de 97.73. In regresie logistică multivariată, valorile PLT/ LYM situate sub acest prag au fost un predictor independent pentru CTO, cu un Odds Ratio de 2.2 (95\%CI=1.154.20, $p=0.02)$. Rezultatele noastre susţin folosirea indicilor trombocitari şi a PLT/LYM ca predictori ai prezenţei CTO la pacienţii cu STEMI.

Cuvinte cheie: infarct miocardic acut, ocluzie totală cronică, trombocite, limfocite

Received: $21^{\text {st }}$ July 2015; Accepted: 24 $4^{\text {th }}$ September 2015; Published: $12^{\text {th }}$ November 2015

\section{Introduction}

Platelets have a key role in the pathophysiology of acute ST-elevation myocardial infarction (STEMI), and also in the progression of atherosclerosis. Platelet indices have been investigated as prognostic markers in coronary artery disease (CAD). Activated platelets have a higher volume, and mean platelet volume (MPV) has been extensively studied in relation to CAD and acute myocardial infarction. A higher MPV has been associated with more extensive myocardial necrosis and subsequent heart failure [1], increased incidence of myocardial no-reflow, as well as mortality [2] in patients presenting with STEMI. Platelet-large cell ratio (P-LCR) and platelet distribution width (PDW) have also been associated with impaired reperfusion in patients with STEMI $[3,4]$. In recent years, platelet-to-lymphocyte ratio (PLT/LYM) and platelet-to neutrophil ratio (PLT/NEU) have been investigated as predictors of no-reflow in STEMI [5].

The severity of chronic CAD is also an important prognostic factor in STEMI. Thrombocytes contribute significantly to the progression of atherosclerosis, mainly due to their proinflammatory effects by recruiting white blood cells (WBC) at vascular injury sites, thus directly amplifying plaque burden [6].

Coronary chronic total occlusion (CTO) is caused by organized thrombi or atherosclerotic plaque progression [7]. A CTO, defined as complete occlusion of a coronary artery branch for at least 3 months, is identified in 15 to $30 \%$ of patients referred for a coronary angiography [8]. The presence of a CTO has been shown to be an important negative prognostic factor for allcause mortality and cardiovascular death in patients presenting with ST-elevation myocardial infarction (STEMI), independent of the presence of atherosclerotic multiple vascular disease [9].

A recent study found a significant association between MPV and the presence of CTO in acute coronary syndrome patients [10]. In our knowledge, there is no specific risk stratification tool to predict the presence of a CTO in STEMI patients. A routinely performed analysis, such as the whole blood count determined on hospital admission in all STEMI patients, would be a 
cheap and easily available method. The aim of this study was to evaluate platelet indices, PLT/ LYM and PLT/NEU as predictors of chronic total occlusion in patients presenting with STEMI.

\section{Methods}

Patients admitted consecutively to the Emergency Institute for Cardiovascular Diseases and Transplantation Tîrgu Mureș for ST-elevation myocardial infarction (STEMI) between January 2011-December 2013 were retrospectively included according to the following criteria: (1) acute STEMI according to the European Society of Cardiology Guideline for Definition of Acute Myocardial infarction, (2) treatment with primary percutaneous coronary intervention $(\mathrm{PCI})$ in the first 12 hours after symptom onset or in 12 to 24 hours in case of ongoing ischemia. Patients with incomplete paraclinical data were excluded, as were patients with a history of coronary artery by-pass surgery or unreadable electrocardiographic tracings: left bundle branch block or pace-maker rhythm. All data was gathered from clinical on-paper and electronic files. The study protocol complied with the declaration of Helsinki and was approved by the local Ethics Committee. Every patient/legal representative signed an informed consent form on personal data usage in scientific purposes on hospital admission.

The chronologic first laboratory measurements performed in the Emergency Department were included in the analysis. For complete blood count determination a SYSMEX KX-21N analyzer was used. Comparability of the measured parameters was estimated by reviewing the laboratory's internal quality control measurements. MPV, PDW and P-LCR were calculated as previously described [11], with normal ranges between 7.4-11.8 fL, 10.0-22.0 fL and 13-43\% respectively. Platelet-to-lymphocyte ratio was calculated by dividing the platelet count to the lymphocyte count.
Chronic total occlusions were identified on the basis of emergency coronary angiograms. The recordings were reviewed by two interventional cardiologists blinded to clinical and laboratory data. A CTO was considered if anterograde flow was absent in a non-infarct related coronary artery, having a diameter of at least 1.5 $\mathrm{mm}$, with distal filling of the lumen through collateral circulation. Patients were divided in two groups according to the presence (CTO+ group) or absence (CTO- group) of a CTO.

Statistical analysis was done using MedCalc Statistical Software version 15.4 (MedCalc Software bvba, Ostend, Belgium; https://www. medcalc.org; 2015). Categorical data were expressed as numbers (percentage) and compared with Fischer's exact test. Continuous data were reported as mean $\pm \mathrm{SD}$ or median (interquartile range) and analyzed with the help of unpaired $t$ test or Mann-Whitney test, as appropriate. Normal distribution was evaluated by the Kolmogorov-Smirnoff test. Receiver-operating characteristic (ROC) curve analysis was used to test the predictive power and to determine cut-off values of different platelet indices for the presence of CTO. In order to identify the independent predictors of CTO, those clinical/paraclinical variables that presented a significant association with the occurrence of this angiographic finding with a probability level $<0.1$ in univariate analysis, were included in a multivariate logistic regression model. All tests were two-tailed and a $\mathrm{p}$ value $<0.05$ was considered as statistically significant.

\section{Results}

A total number of 334 patients were included in the present study, 48 patients $(14.37 \%)$ in the CTO+ group and $286(85.63 \%)$ in CTOgroup. Except for diabetes mellitus, the groups were similar regarding cardiovascular risk factors (Table I). For the laboratory measurements, 
the maximum coefficients of variance during the study period were $4.47 \%$ for WBC count and $7.05 \%$ for PLT count. In univariate analysis, MPV, PDW and P-LCR were significantly larger in patients with CTO. Whereas PLT/LYM was significantly lower in patients with $\mathrm{CTO}$, no difference was observed between the two groups regarding PLT/NEU (Table I).

Receiver-operating characteristic curve analysis identified area under the curve values of 0.60 (95\%CI: $0.55-0.66, p=0.02), 0.59$ (95\%CI: $0.54-0.65, p=0.03), 0.61 \quad(95 \% \mathrm{CI}: 0.56-0.67$, $\mathrm{p}=0.01)$ and $0.62(95 \% \mathrm{CI}: 0.57-0.67, \mathrm{p}<0.01)$ for MPV, P-LCR, PDW and PLT/LYM (Fig. 1) in predicting the presence of a CTO on emergency coronary angiography, with cut-off values at $10.2 \mathrm{fL}, 12 \%, 28 \%$ and 97.73 , respectively.
Multivariate logistic regression analysis identified the PLT/LYM as an independent predictor for CTO (Table 1); values of this ratio situated below 97.73 were associated with the incidence of a CTO with an OR of $2.2(95 \% \mathrm{CI}$ $1.15-4.2, \mathrm{p}=0.02$ ).

\section{Discussion}

The main finding of the present study was that the presence of a CTO - an independent determinant of worse short- and long-term outcomes after STEMI - is predicted by simple parameters available on the complete blood count determined at hospital admission: platelet indices and PLT/LYM.

Table I. Baseline clinical parameters and laboratory measurements of the enrolled patients. Values are presented as medians (interquartile range) or number (percentage). Mann-Whitney and Chi-square tests were used as univariate analysis. WBC - white blood cell count; MPV - mean platelet volume; P-LCR platelet-large cell ratio; PDW - platelet distribution width; PLT/LYM - platelet-to-lymphocyte ratio; PLT/ NEU - platelet-to-neutrophil ratio.

\begin{tabular}{lcccc}
\hline & CTO+ & CTO- & \multicolumn{2}{c}{$\mathrm{P}$} \\
\cline { 4 - 5 } & $\mathrm{n}=48$ & $\mathrm{n}=286$ & $\begin{array}{c}\text { univariate } \\
\text { analysis }\end{array}$ & $\begin{array}{c}\text { multivariate } \\
\text { analysis }\end{array}$ \\
\hline Age (years) & $63(26-71)$ & $62(53-72)$ & 0.35 & - \\
Female/Male & $20 / 28$ & $83 / 203$ & 0.09 & 0.07 \\
Weight (kg) & $80(71-89)$ & $75(69-87)$ & 0.06 & 0.07 \\
Smoking & $13(27 \%)$ & $124(43.4 \%)$ & 0.09 & 0.16 \\
Diabetes & $19(39.5 \%)$ & $66(23 \%)$ & $\mathbf{0 . 0 1}$ & 0.52 \\
Arterial Hypertension & $35(72.9 \%)$ & $206(72 \%)$ & 0.59 & - \\
Serum creatinine (mg/dL) & $1.05(0.79-1.4)$ & $0.98(0.83-1.18)$ & 0.39 & - \\
Platelet count (N/mm3) & $217000(191750-257000)$ & $239000(198000-280000)$ & 0.08 & - \\
WBC (N/mm3) & $11400(9100-14000)$ & $11250(9000-13825)$ & 0.65 & - \\
Hemoglobin (mg/dL) & $14.4(12.73-15.38)$ & $14.2(13.2-15)$ & 0.73 & - \\
MPV (fL) & $10.35(9.725-11)$ & $9.9(9.4-10.7)$ & $\mathbf{0 . 0 2}$ & 0.60 \\
P-LCR (\%) & $29(24.25-34)$ & $25(21-61)$ & $\mathbf{0 . 0 1}$ & 0.32 \\
PDW (fL) & $14(13-15.75)$ & $13(12-14.25)$ & $\mathbf{0 . 0 3}$ & 0.17 \\
PLT/LYM & $105.2(75.86-159.1)$ & $137(97-188.1)$ & $\mathbf{0 . 0 0 7}$ & $\mathbf{0 . 0 2}$ \\
PLT/NEU & $26.49(21.59-35.45)$ & $28.45(21.58-37.11)$ & 0.35 & - \\
\hline
\end{tabular}



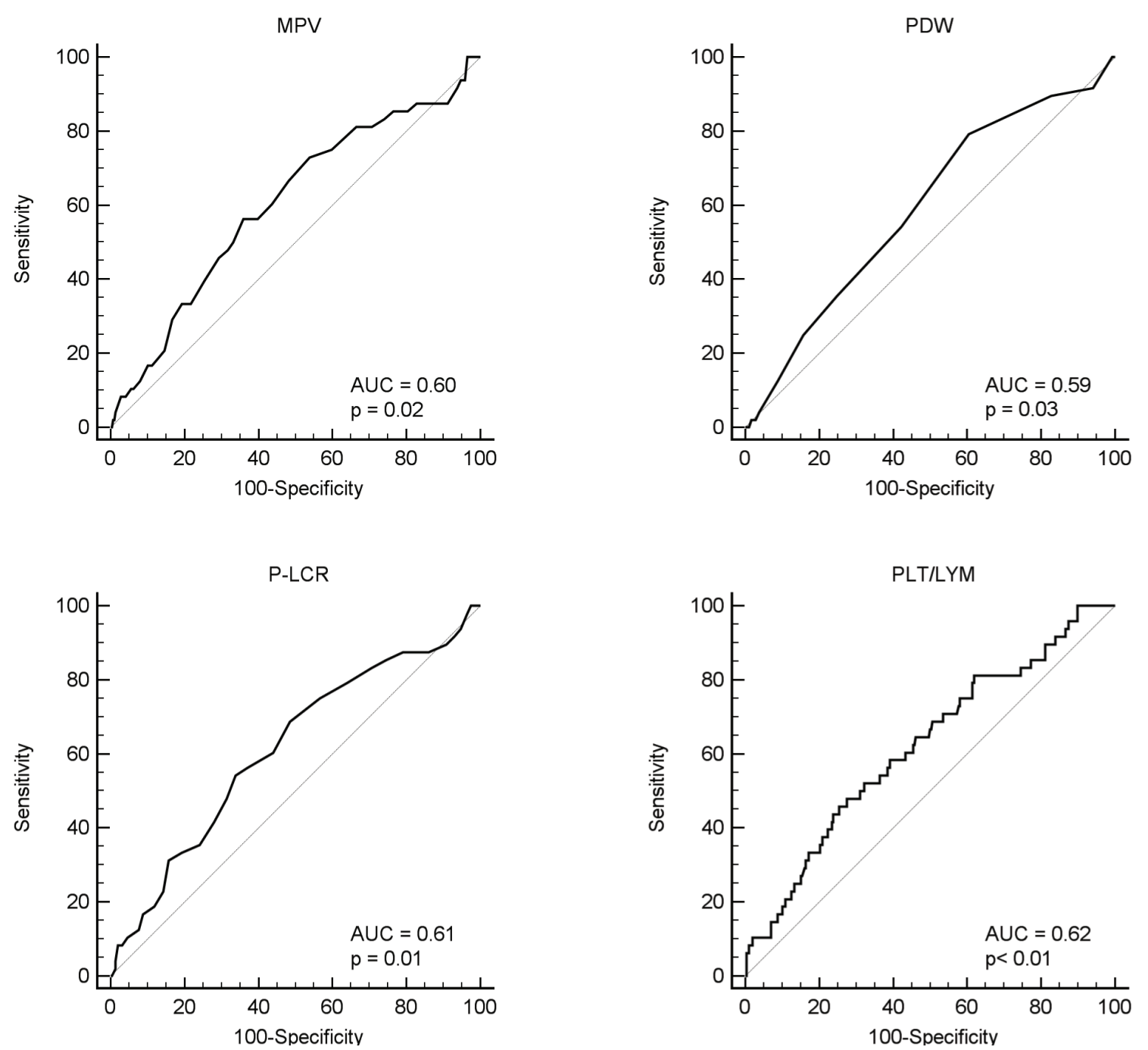

Figure 1. Receiver-operating characteristic curve analysis of MPV (a), P-LCR (b), PDW (c), Platelet-tolymphocyte ratio (d) data for the prediction of chronic total occlusion.

\section{Platelet indices and CTO}

In our study, patients presenting with STEMI who associated CTO had higher MPV than patients without CTO. Kurtul et al. [10] recently published similar results, showing a strong independent association between CTO and MPV. In that study, patients with acute coronary syndromes with and without ST-segment elevation were included, and a cut-off value of $8.65 \mathrm{fL}$ for MPV was found to have a high sensitivity and specificity. In our study a cut-off value of $10.2 \mathrm{fL}$ was determined for STEMI patients. As the MPV normal range is between $7.4 \mathrm{fL}$ and $11 \mathrm{fL}$, a higher cut-off value seems to be more feasible for risk prediction.

The proportion of platelets with an MPV higher than $12 \mathrm{fL}$ is reflected by P-LCR. Compared to healthy controls, P-LCR is higher in patients with acute myocardial infarction and unstable angina $[12,13]$. None of the published 
studies correlating platelet indices with CAD and especially with STEMI present data on the associations between CTO and P-LCR. In our study, high P-LCR was a predictor of CTO.

Another important marker of platelet size and activation is PDW [14]. Our results show that in patients presenting with STEMI, PDW can predict the presence of CTO. The association between CTO and PDW has also been showed by Vatankulu et al. [15] in patients with stable CAD who underwent coronary artery angiography. De Luca et al. [16] found no association between PDW and the extent of CAD, but patients with three vessels affected had a tendency towards higher PDW values.

It has been observed that as MPV [17] and PDW [16] are higher, the platelet count is lower, probably due to increased platelet consumption and compensatory production of platelets in the bone marrow [17]. This might suggest that the increase in PDW in our patients is not only due to the acute event, but is also probably a marker of chronic inflammation and high platelet turnover. We observed a statistical trend for lower platelet count in the $\mathrm{CTO}+$ group, as did Kurtul et al [10]. This may emphasize the role of chronic inflammation causing the progression of atherosclerosis towards CTO [18].

\section{Platelet-to-lymphocyte ratio as an indepen- dent predictor of CTO in STEMI patients}

During the atherosclerotic process, lymphocytes, especially $\mathrm{T}$ cells are recruited in the vessel wall together with macrophages. $\mathrm{T}$ cells become activated and amplify the inflammatory response, contributing to the progression of atherosclerosis [18]. In our study, low PLT/LYM was a strong independent predictor of CTO. This combined marker has been investigated recently in multiple studies as a marker of more severe atherosclerosis and outcomes after elective and emergency PCI. A high PLT/LYM was associated with more complex CAD in patients with acute coronary syndromes [19,20], and with complete occlusion of the infarct related artery in patients with STEMI [21]. In a recent study a higher incidence of CTO was found in patients with a PLT/LYM greater than 116 [19]. These observations are in contrast with our findings. It was hypothesized that in patients with acute coronary syndromes the lymphocyte count is lower due to stress-induced cortisol secretion [20]. However, higher cortisol levels would further decrease the production of lymphocytes but already circulating cells could not instantly decrease in numbers. In our study, the blood for whole blood cell count was harvested in less than 24 hours after the onset of ischemic symptoms. Interestingly, both high [21] and low [22] lymphocyte counts have been associated with cardiovascular risk factors.

Furthermore, as MPV, PDW and P-LCR were associated with CTO and as they are inversely correlated with platelet count, PLT/LYM was also expected to be lower in patients with CTO.

This study has some limitations. Firstly, due to the retrospective design, data on previous antiplatelet treatment were not available. Also, the time frame between onset of pain and blood sampling ranged between 1 and 24 hours, which might have influenced our results. Our hypothesis-generating findings should be further confirmed by prospective clinical studies.

\section{Conclusion}

Platelet indices such as MPV, PDW and P-LCR can predict the presence of CTO in patients presenting with STEMI. A lower PLT/ LYM was also associated with CTO. These parameters could be used in order to stratify risk in patients with STEMI. A prospective study to assess the changes of these parameters in time would help better understand their role as predictors of CAD progression. 


\section{Acknowledgement}

This study was funded by the European Social Found, Human Resources Development Operational Programme 2007-2013, project no. POSDRU/159/1.5/S/136893.

\section{References}

1. Boos CL, Lip GYH. Assessment of mean platelet volume in coronary artery disease - What does it mean?. Thrombosis Research. 2007; 120:11-13 DOI: 10.1016/j. thromres.2006.09.002

2. Huczek Z, Kochman J, Filipiak KJ, Horszczaruk GJ, Grabowski M, Piatkowski R, et al. Mean platelet volume on admission predicts impaires reperfusion and long-term mortatilty in acute myocardial infarction trated with primary percutaneous coronary intervention. J Am Coll Cardiol. 2005; 46:284-90. DOI: 10.1016/j. jacc.2005.03.065

3. Cakici M, Cetin M, Balli M, Akturk E, Dogan A, Oylumlu M, et al. Predictors of thrombus burden and no-reflow of infarct-related artery in patients with ST-segment elevation myocardial infarction: importance of platelet indices. Blood Coagul Fibrinolysis. 2014 Oct;25(7):70915. DOI: $10.1097 / \mathrm{MBC} .0000000000000130$

4. Celik T, Kaya MG, Akpek M, Gunebakmaz O, Balta S, Sarli B et al. Predictive value of admission platelet volume indices for in-hospital major adverse cardiovascular events in acute ST-segment elevation myocardial infarction. Angiology. 2015 Feb;66(2):155-62. DOI: 10.1177/0003319713513493

5. Kurtul A, Yarlioglues M, Murat SN, Ergun G, Duran M, Kasapkara HA, et al. Usefulness of the platelet-to-lymphocyte ratio in predicting angiographic reflow after primary percutaneous coronary intervention in patients with acute st-segment elevation myocardial infarction. Am J Cardiol. 2014; 114:342-47. DOI: 10.1016/j.amjcard.2014.04.045

6. Lievens D, von Hundelshausen P. Platelets in atherosclerosis. Thromb Haemost. 2011 Nov; 106(6):827-36. DOI: 10.1160/TH11-08-0592

7. Burke A, Tavora F, Pathology of coronary atherosclerosis, Practical Cardiovascular Pathology, Lippincott Williams\&Wilkins, Philadelphia, 2011, pages 83-84.

8. 2013 ESC guidelines on the management of stable coronary artery disease: the Task Force on the management of stable coronary artery disease of the European Society of Cardiology. Taks Force members. Eur Heart J. 2013 Oct; 34(38):2949-3003. DOI: 10.1093/eurheartj/ eht296

9. O'Connor SA, Garot P, Sanguineti F, Hoebers LP, Unterseeh T, Benamer $\mathrm{H}$, et al. Meta-analysis of the impact of mortality of non-infarct related artery coronary chronic total occlusion in patients presenting with ST-segment elevation myocardial infarction. Am J Cardiol. 2015 Jul 1;116(1):8-14. DOI: 10.1016/j.amjcard.2015.03.031

10. Kurtul A, Yarlioglues M, Murat SN, Celik IE, Demircelik MB, Ocek AH, et al. Predictors of Chronic Total Occlusion in Nonculprit Artery in Patients With Acute Coronary Syndrome: Mean Platelet Volume and Uric Acid. Angiology. 2015 Jul;66(6):553-9. DOI: 10.1177/0003319714542998

11. Olteanu AL, Mihaila RG, Catana AC, Flucus O, Bus C, Mihalache M. Platelet indices in Philadelphia-negative chronic myeloproliferative neoplasms. Rev Romana Med Lab. 2015;23(2):169-77. DOI: 10.1515/rrlm2015-0012

12. Khandekar MM, Khurana AS, Deshmukh SD, Kakrani AL, Katdare AD, Inamdar AK. Platelet volume indices in patients with coronary artery disease and acute myocardial infarction: an Indian scenario. J Clin Pathol. 2006 Feb; 59:146-149. DOI: 10.1136/jcp.2004.025387

13. Dehghani MR, Taghipour-Sani L, Rezaei Y, Rostami R. Diagnostic importance of admission platelet volume indices in patients with acute chest pain suggesting acute coronary syndrome. Indian Heart J. 2014 Nov-Dec; 66(6):622-628. DOI: 10.1016/j.ihj.2014.10.415

14. Vagdatli E, Gounari E, Lazaridou E, Katsibourlia E, Tsikopoulou F, Labrianou I. Platelet distribution width: a simple, practical and specific marker of activation of coagulation. Hippokratia. 2010;14(1):28-32.

15. Vatankulu MA, Sonmez O, Ertas G, Bacaksiz A, Turfan M, Erdogan E, et al. A new parameter predicting chronic total occlusion of coronary arteries: platelet distribution width. Angiology. 2014; 65(1): 60-4. DOI: 10.1177/0003319713502702 DOI: $10.1177 / 0003319713486339$

16. De Luca G, Venegoni L, Iorio S, Secco GG, Cassetti E, Verdoia $\mathrm{M}$ et al. Platelet distribution width and the extent of coronary artery disease: results from a large prospective study. Platelets. 2010; 21(7):508-14. DOI: 10.3109/09537104.2010.494743 
17. McCabe DJ, Harrison P, Sidhu PS, Brown MM, Machin SJ. Circulating reticulated platelets in the early and late phases after ischaemic stroke and transient ischaemic attack. Br J Haematol 2004;126:861-9. DOI: 10.1111/j.1365-2141.2004.05137.x

18. Legein B, Temmerman L, Biessen EAL, Lutgens E. Inflammation and immune system interactions in atherosclerosis. Cell Mol Life Sci. 2013; 70:3847-69. DOI: 10.1007/s00018-013-1289-1

19. Kurtul A, Murat SN, Yarlioglues M, Duran M, Ergun G, Acikgoz SK, et al. Association of platelet-to-lymphocyte ratio with severity and complexity of coronary artery disease in patients with acute coronary syndrome. Am J Cardiol. 2014; 114:972-78. DOI: 10.1016/j.amjcard.2014.07.005

20. Dehghani MR, Taghipour-Sani L, Rezaei Y, Rostami R. Diagnostic importance of admission platelet volume indices in patients with acute chest pain suggesting acute coronary syndrome. Indian Heart J. 2014 Nov-Dec; 66(6):622-8. DOI: 10.1016/j.ihj.2014.10.415
21. Acet H, Ertaş F, Akıl MA, Özyurtlu F, Yıldız A, Polat $\mathrm{N}$, et al. Novel predictors of infarct-related artery patency for ST-segment elevation myocardial infarction: Platelet-to-lymphocyte ratio, uric acid, and neutrophil-to-lymphocyte ratio. Anatol J Cardiol. 2015 Aug;15(8):648-56. DOI: 10.5152/akd.2014.5592

22. Thomson SP, McMahon LJ, Nugent CA. Endogenous cortisol: a regulator of the number of lymphocytes in peripheral blood. Clin Immunol Immunopathol 1980;17:506e514.

23. Szodoray P, Timar O, Veres K, Der H, Szomjak E, Lakos G, et al. TH1/TH2 imbalance, measured by circulating and intracytoplasmic inflammatory cytokinesimmunological alterations in acute coronary syndrome and stable coronary artery disease. Scand J Immunol. 2006 Sep; 64(3):336-44. DOI: 10.1111/j.13653083.2006.01816.x

24. Nunez J, Minana G, Bodi V, Nunez E, Sanchis J, Husser O, et al. Low lymphocyte count and cardiovascular diseases. Curr Med Chem 2011;18(21):3226-33. DOI: 10.2174/092986711796391633 